\title{
OPEN A large self-transmissible resistance plasmid from Nigeria contains genes that ameliorate a carrying cost
}

\author{
Rubén Monárrez ${ }^{1}$, Molly Braun ${ }^{1}$, Olivia Coburn-Flynn ${ }^{1}$, João Botelho ${ }^{2}$, \\ Babatunde W. Odetoyin ${ }^{3}$, Jose I. Otero-Vera ${ }^{1}$, Naa Kwarley Eyiram Quartey ${ }^{1}$, Luísa Peixe ${ }^{2}$, \\ Aaron O. Aboderin ${ }^{3} \&$ Iruka N. Okeke ${ }^{1,4^{*}}$
}

Antimicrobial resistance is rapidly expanding, in a large part due to mobile genetic elements. We screened 94 fecal fluoroquinolone-resistant Escherichia coli isolates from Nigeria for six plasmidmediated quinolone resistance (PMOR) genes. Sixteen isolates harbored at least one of the PMOR genes and four were positive for aac-6-Ib-cr. In one strain, aac-6-Ib-cr was mapped to a $125 \mathrm{~Kb}$ selftransmissible IncFII plasmid, pMB2, which also bears $b l a_{C T X-M-15}$, seven other functional resistance genes and multiple resistance pseudogenes. Laboratory strains carrying PMB2 grew faster than isogenic strains lacking the plasmid in both rich and minimal media. We excised a $32 \mathrm{~Kb}$ fragment containing transporter genes and several open-reading frames of unknown function. The resulting $93 \mathrm{~Kb}$ miniplasmid conferred slower growth rates and lower fitness than wildtype pMB2. Trans-complementing the deletion with the cloned sit $A B C D$ genes confirmed that they accounted for the growth advantage conferred by pMB 2 in iron-depleted media. pMB2 is a large plasmid with a flexible resistance region that contains loci that can account for evolutionary success in the absence of antimicrobials. Ancillary functions conferred by resistance plasmids can mediate their retention and transmissibility, worsening the trajectory for antimicrobial resistance and potentially circumventing efforts to contain resistance through restricted use.

Ciprofloxacin was introduced into clinical medicine in the 1980s. It however only became affordable, and therefore widely available in Nigeria in the 2000s, once its patent expired. Fluoroquinolone resistance subsequently emerged in Nigeria ${ }^{1}$ and poses an enormous clinical challenge because ciprofloxacin and other orally active quinolones represent the last accessible therapeutic option for many infected patients. High-level fluoroquinolone resistance is most commonly attributable to multiple mutations in the quinolone-resistance-determining regions of quinolone targets $g y r A$ and parC. In non-mutator E. coli strains, the mutation rate is $10^{-9}$ or lower so that step-wise mutation to resistance is predicted to be slow. Resistance evolved quickly in Nigeria, as in many other parts of the world, supporting the idea that low-level resistance mechanisms may help to protect susceptible strains until they accumulate the 2-4 mutations required for high-level resistance ${ }^{2}$. We have previously shown that early quinolone resistant isolates showed elevated efflux capacities ${ }^{1}$ but the contribution of plasmid-mediated quinolone resistance (PMQR) in Nigeria and other African countries has been investigated only minimally.

Plasmid-encoded resistance genes most significant in quinolone resistance can be grouped into three functional categories. The qnr genes, suspected to be the most common PMQR genes globally, encode members of a pentapeptide-repeat family. They confer resistance through direct binding of their gene products to the quinolone targets and thus prevent interactions between the drug and the target enzyme ${ }^{3,4}$. A second category of quinolone-resistance genes, qepA and $o q x A$, encode efflux pumps. QepA is a member of the 14-transmembrane-segment major facilitator family of transporters and functions as a proton antiporter efflux pump system that is especially efficient at exporting quinolones but which can also export other antimicrobials

${ }^{1}$ Department of Biology, Haverford College, Pennsylvania, USA. ${ }^{2}$ UCIBIO/REQUIMTE, Laboratory of Microbiology, Porto, Portugal. ${ }^{3}$ Department of Medical Microbiology and Parasitology, Obafemi Awolowo University, Ile-Ife, Nigeria. ${ }^{4}$ Department of Pharmaceutical Microbiology, Faculty of Pharmacy, University of Ibadan, Ibadan, Nigeria. *email: iruka.n.okeke@gmail.com 


\begin{tabular}{|c|c|c|}
\hline & Individuals & Strains \\
\hline $\begin{array}{l}\text { Plasmid-mediated } \\
\text { quinolone resistant gene }\end{array}$ & $\begin{array}{l}\text { Unique individuals carrying } \\
\text { ciprofloxacin non-susceptible strains }\end{array}$ & $\begin{array}{l}\text { Total number of ciprofloxacin } \\
\text { non-susceptible strains }(n=94)\end{array}$ \\
\hline$q n r A$ & 0 & 0 \\
\hline$q n r B$ & 0 & 0 \\
\hline$q n r S$ & 2 & 2 \\
\hline$q e p A$ & 2 & 2 \\
\hline$o q x A B$ & 8 & 9 \\
\hline$* a a c\left(6^{\prime}\right)-I b$ & 26 & 37 \\
\hline$a a c\left(6^{\prime}\right)-I b-c r$ & 2 & 4 \\
\hline
\end{tabular}

Table 1. PMQR genes identified by PCR in ciprofloxacin non-susceptible Escherichia isolates. *Includes the PMQR $a a c\left(6^{\prime}\right)-I b-c r$ as well as non-ciprofloxacin resistance conferring $a a c\left(6^{\prime}\right)-I b$.

including erythromycin, acriflavine, and ethidium bromide. The plasmid-encoded efflux pump, encoded by the oq $x A B$ genes, is a member of the resistance-nodulation-division family of multidrug efflux pumps and was first identified as conferring resistance to the porcine growth enhancer quinoxaline-di-N-oxide, a compound that also inhibits DNA synthesis ${ }^{5}$. oq $x A B$, can also confer resistance to chloramphenicol in addition to the quinolones nalidixic acid and ciprofloxacin ${ }^{5,6}$. The $o q x A$ gene appears to be rare among isolates identified in Denmark, Sweden, and South Korea. Recent reports suggest that it is common in South Africa and potentially other parts of the continent but there are few studies performed in sub-Saharan Africa which have sought these genes ${ }^{5,7-11}$.

The third and final PMQR category contains only one member. $a a c\left(6^{\prime}\right)-I b-c r$ is an aminoglycoside acetyltransferase $^{12}$. The standard $a a c\left(6^{\prime}\right)-I b$ allele confers aminoglycoside resistance but two SNPs generate an $a a c\left(6^{\prime}\right)-I b-c r$ allele that confers resistance to ciprofloxacin and norfloxacin, which have unsubstituted piperazinyl groups, but not to other quinolones ${ }^{12}$. The $a a c\left(6^{\prime}\right)-I b-c r$ allele was initially identified by Robicsek et al. from clinical E. coli isolates originating in China ${ }^{4}$. Like the other PMQR genes, with the exception of $o q x A$, aac $\left(6^{\prime}\right)-I b$-cr has previously been identified in isolates from West Africa ${ }^{13}$. On its own, $a a c\left(6^{\prime \prime}\right)-I b-c r$ confers only low-levels of resistance to ciprofloxacin but the gene enables target-site mutants to survive at drug concentrations achieved in the clinic. Additionally, $a a c\left(6^{\prime}\right)-I b-c r$ is frequently found on plasmids with other resistance genes including qnr genes, and $q e p A$, as well as ß-lactamases ${ }^{2,4}$.

Although the aforementioned genes have been found throughout the globe, there remains a dearth of information on the nature of quinolone resistance in Africa and the relative importance of PMQR genes on the continent. Because PMQR genes, as their name suggests, are plasmid-borne, the mobile elements that transmit them have the propensity to bring in other resistance genes and/or non-resistance characteristics, which in turn could influence strain survival, virulence and transmissibility. The selective success of some $E$. coli lineages is attributed fully or in part to resistance gene-bearing elements, which ${ }^{14}$ have also been known to confer adherence, virulence, bacteriocin immunity and evolutionary fitness ${ }^{14-16}$.

We recently examined antimicrobial resistance in Escherichia coli from mother-infant pairs in Nigeria and found that 94 of $1,098(8.6 \%)$ of the isolates were fluoroquinolone resistant ${ }^{17,18}$. We sought to determine the proportion of these strains carrying PMQR genes and the identity of these genes. While we have previously described a plasmid carrying qnrS1 from a Nigerian isolate ${ }^{19}$, no local information is available about the context of $a a c\left(6^{\prime}\right)-I b-c r$. We therefore screened for $a a c\left(6^{\prime}\right)-I b-c r$ in this recently obtained epidemiological strain collection and then sequenced and characterized a $a a c\left(6^{\prime}\right)$ - Ib-cr-bearing plasmid identified from one of the strains.

Results

Plasmid-encoded quinolone resistance genes in fluoroquinolone resistant isolates from Nigeria. Of $1,098 \mathrm{fecal} E$. coli isolates originally recovered from 134 mother-infant pairs, 94 (8.6\%) were ciprofloxacin-resistant and were screened for six PMQR genes. The PCR screen initially revealed that $a a c\left(6^{\prime}\right)-I b$ was common among ciprofloxacin resistant isolates with 37 (39.3\%) being positive for the gene as shown in Table 1. However, upon BstI restriction analysis necessary to confirm the ciprofloxacin resistance-conferring allele, only four of the isolates with $a a c\left(6^{\prime}\right)-I b$ genes (10.8\%) proved to be the $a a c\left(6^{\prime}\right)-I b$-cr allele (Table 1). $q n r A$ and $q n r B$ were not detected at all whilst qnrS1, which we have previously detected in a different strain set from Nigeria ${ }^{19}$, was found in two of the isolates. Overall, $o q x A B$ was detected in nine isolates (including two that were positive for $\left.a a c\left(6^{\prime}\right)-I b-c r\right)$ and was therefore the most common PMQR recorded but aac $\left(6^{\prime}\right)-I b-c r$ was the most common quinolone-specific mechanism (Table 1). We therefore went on to characterize M63c, one of the strains bearing $\operatorname{aac}\left(6^{\prime}\right)-I b-c r$ alleles.

Strain M63c was mucoid on MacConkey and eosin methylene blue plates with an API 20E profile pointing to 'group C E. coli', which are now classified as Escherichia fergusonnii. We amplified and sequenced the 16S rRNA gene of M63c and found the sequence (Accession number SUB5013267) was 99\% identical to that of Escherichia fergusonii type strain ATCC 35469 (Accession number NR_074902.1). However, Maheux et al. ${ }^{20}$ reported that the $a d k$, gyrB and recA genes were more useful for speciating Escherichia spp. than 16S rRNA. Alleles of those genes carried by $\mathrm{M} 63 \mathrm{c}$ were identical to $E$. coli alleles. We additionally sequenced $f u m C, i c d, m d h$ and purA genes of the strain and multilocus sequence typed the isolate as an E. coli ST167 strain. E. coli ST167 strains are encountered around the globe, frequently multiply resistant and often expressing extended-spectrum $\beta$-lactamases (ESBLs) ${ }^{21}$. We extracted a large plasmid DNA from strain M63c and electroporated it into DH5 $\alpha$ cells (DH5 $\alpha \mathrm{E}$ from Thermo Scientific). Transformants were obtained on neomycin $(50 \mathrm{mg} / \mathrm{ml})$ plates but not on ciprofloxacin $(1 \mathrm{mg} / \mathrm{ml})$. 


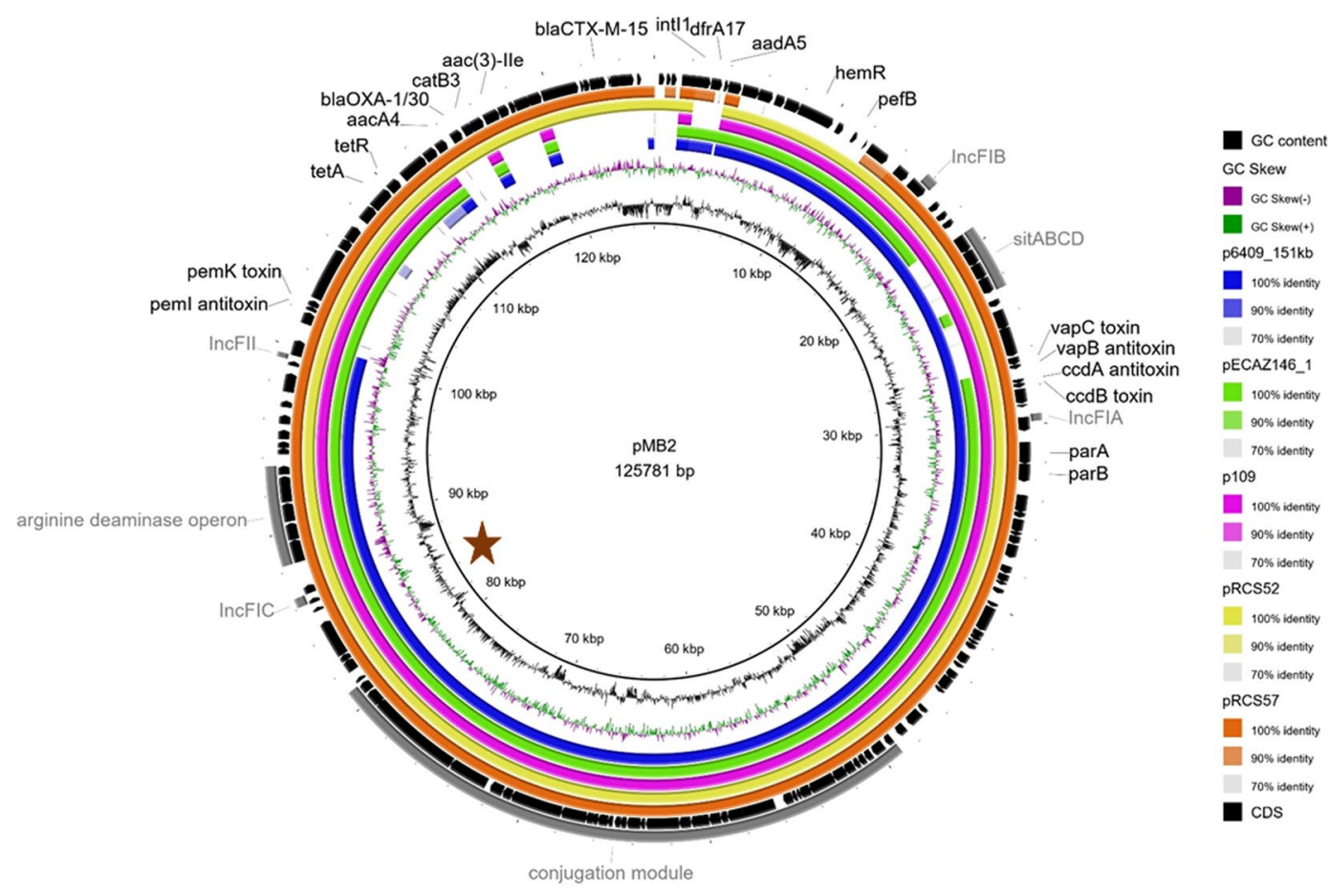

Figure 1. Circular plot illustrating the general features of pMB2. The figure shows the organization of $\mathrm{pMB} 2$ ORFs in black and a BLASTn comparison between pMB2 and the five best hits E. coli plasmids retrieved from NCBI (from the innermost to the outermost circles, plasmids p6409, pECAZ146_1, p109, pRCS52 and pRCS57 with the GenBank accession numbers CP010372.1, CP018990.1, CP023372.1, LO017736.1 and LO017738.1, respectively). A brown star marks the likely location of the origin of replication.

Each transformant showed reduced susceptibility (but not full resistance) to ciprofloxacin and nalidixic acid as well as resistance to tetracycline, ampicillin, neomycin/kanamycin, trimethoprim and sulphonamides but not chloramphenicol. All transformants had identical plasmid DNA BamHI, and SalI restriction profiles and susceptibility patterns and carried a single large plasmid, which we termed pMB2.

Sequence of Plasmid pMB2. pMB2 was Sanger-sequenced and shot-gun assembled into a 125,782 base pair circular replicon (Genbank Accession number MK370889). pMB2 has a G + C content of 51.73\% (Fig. 1), which is comparable to that of the Escherichia coli chromosome ${ }^{22}$ A maximal number of 323 ORFs of approximately 100 or more base pairs in length were predicted but additional evidence supports only 145 of these as encoding real or hypothetical genes. The plasmid contains a full IncFII-type conjugation region of 32 genes including all 25 of the consecutive transfer region genes with known functions in the conjugation process ${ }^{23}$.

In silico replicon typing revealed that the Plasmid Sequence Type of pMB2 is [F36:A4:B1]. The pMB2 plasmid carries replication-associated proteins associated with IncFIA, IncFIB, IncFIC and IncFII plasmids. The IncFIC RepA1 protein is coded by an ORF at 86,659 bp on the plasmid, which is close to the major shift in $\mathrm{G}+\mathrm{C}$ skew seen at $81,000 \mathrm{bp}$ and likely marking the origin of replication (Fig. 1). pMB2 is rich in mobility genes with at least 26 transposases or transposase-like ORFs, as well as up to six other integrases and recombinases encoded. Almost all functional units on the plasmid are flanked by insertion sequences. pMB2 carries genes encoding several toxin-antitoxin systems $c c d A / c c d B, v a p B / v a p C$ and $p e m I / p e m K$. It also carries genes encoding the SOS response inhibiting proteins PsiA and PsiB. Between positions 88,324 and 93,566 is a complete, six gene arginine deaminase operon, which could potentially catabolize arginine to ammonia.

pMB2 is predicted to encode at least three transport systems. The EamA-like domain-containing drug/metabolite and carboxylate/amino acid/amine transporter (Pfam00892; located at 107699-108583), is found in a variety of integral membrane proteins; there is no known function for these genes but they could possibly contribute to antimicrobial resistance. A hypothetical divalent ion transport system (located between 10,045 and 7,247, on the complementary strand) is composed of two proteins coded in an operon: conserved hypothetical pMB2_00012 a (pfam 10670) $)^{24}$ and HmuR/hemR, which is a Ton-B dependent hemoglobin-hemin receptor localized to the bacteria's outer membrane ${ }^{25}$. The third transport system, and the best studied, is encoded by sit $A B C D$ located on the forward strand of the plasmid between 19,195 and 22,644. SitABCD form an effective ferrous iron uptake system earlier described in Salmonella enterica and Shigella ${ }^{26,27}$. SitA is a periplasmic binding protein, SitB is the ATP-binding component, SitC functions as a permease and SitD is the inner membrane component of the system.

pMB2 bears eight genes conferring resistance to six different drug classes (Fig. 2). An IS26-composite transposon flanks an incomplete class I integron carrying a $d f r A 17$ gene (encoding resistance to trimethoprim) and an incomplete aadA5 gene. The tetracycline resistance gene tet $A$ (alongside tet $R$, encoding the repressor of the tetracycline resistance element) is located within the remnants of a Tn1721 transposon. Next to this region, another 


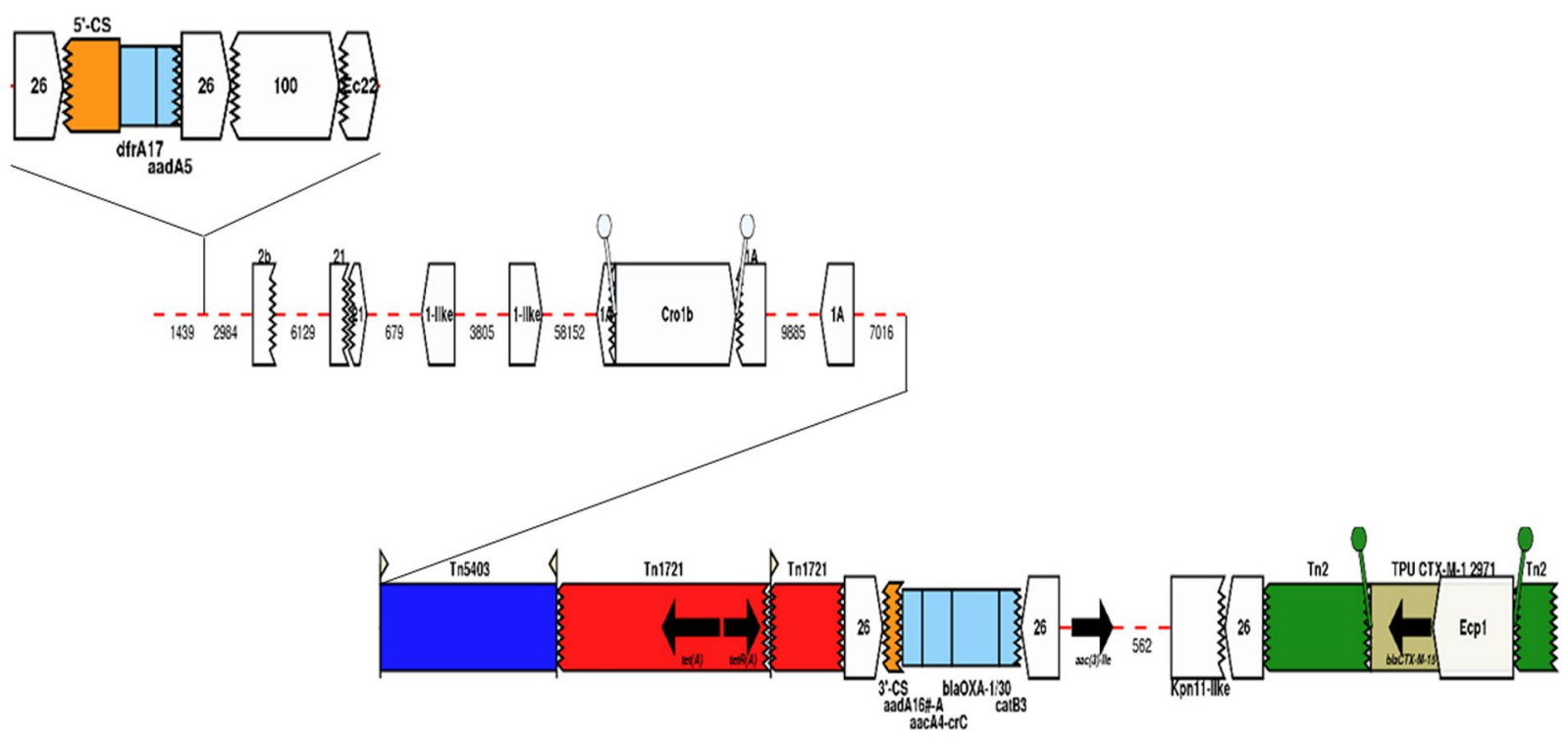

Figure 2. Genetic context of the pMB2 antimicrobial resistance region. Arrows indicate the direction of transcription for genes. Gene cassettes are shown by pale blue boxes, the conserved sequences $\left(5^{\prime}\right.$ and $3^{\prime}$-CS) of integrons as orange boxes and insertion sequences as white block arrows labelled with the IS number/ name, with the pointed end indicating the inverted right repeat (IRR). Unit transposons are shown as boxes of different colors and their IRs are shown as flags, with the flat side at the outer boundary of the transposon. Direct repeats are shown as 'lollipops' of the same color. The zig-zag line indicates which end of the feature is missing. Gaps $>50 \mathrm{bp}$ are indicated by dashed red lines and the length in bp given.

IS26-composite transposon was identified, carrying an incomplete class I integron with a $|a a d A 16| a a c\left(6^{\prime}\right)-I b$-cr|$b l a_{\text {OXA-1/30 }}|\Delta c a t B 3|$ gene cassette array encoding resistance to aminoglycosides, fluoroquinolones, beta-lactams and phenicol. As stated previously, the $a a c\left(6^{\prime}\right)-I b-c r$ gene, also named $a a c A 4-c r C$, confers resistance to aminoglycosides and the broad-spectrum antimicrobial ciprofloxacin due to a $\mathrm{T}$ to $\mathrm{C}$ mutation at nt 283 and a $\mathrm{G}$ to $\mathrm{T}$ mutation at nt 514 . Following $b l a_{O X A-1}$ is catB3, which normally inactivates chloramphenicol through acetylation ${ }^{28}$ but which is not active in pMB2 due to a truncated cassette region. Next to the IS26-composite transposon is an aac(3)-II gene, conferring gentamicin resistance. Finally, a transposition unit carrying bla $_{\mathrm{CTX}-\mathrm{M}-15}$, which confers resistance to oxyiminocephalosporins, and ISEcp 1 was found within the remnants of a Tn 2 transposon. This insertion unit is flanked by 5 -bp direct repeats ( $5^{\prime}$-TATGA-3'), suggesting the en bloc transposition of these elements within the Tn2 transposon (Fig. 2).

pMB2 is similar to many other resistance plasmids in the database that have been isolated from around the world. Figure 1 compares the sequences of four of these plasmids with pMB2 illustrating that the plasmids are almost completely conserved and almost perfectly syntenic. In particular, conjugation and arginine deaminase genes are highly conserved among the plasmids whereas their resistance regions are expectedly the most variable. Only three of the plasmids carry all the putative transport genes, however all of them have at least two of them.

pMB2 is self-transmissible. While the plasmid as a whole is replete with transposable elements and insertion sequences, and contains multiple antimicrobial resistance genes, some no longer functional, others redundant, the conjugation region of pMB2 is not interrupted. The transfer genes of pMB2 are organized similarly to those of the F plasmid ${ }^{29}$ and identical to those on the other five plasmids we compared with pMB2 in Fig. 1. Conjugation from DH5 $\alpha$ (pMB2) to EC1502 (rifampicin resistant) on solid media occurred at the rate of $1.8 \times 10^{-5}$ to $8 \times 10^{-6}$.

Three other Escherichia isolates from the individual from whom strain M63c was isolated had been archived along with two isolates from her infant ${ }^{17}$. As shown in Table 2, strain M63c was the only quinolone-non-susceptible isolate of this set. We screened all six isolates for the presence of the $a a c\left(6^{\prime}\right)-I b-c r$ allele and pMB2 and found that they were present in strain M63b, as well as original source strain M63c. While they differed in quinolone resistance, strain M63b and M63c shared otherwise identical susceptibility patterns. We sequenced quinolone resistance determining regions of $g y r A$ and $\operatorname{parC}$ in both strains and found that quinolone-susceptible strain M63b contained no SNPs whilst resistant strain M63c carried Ser83Leu and Asp87Asn mutations in GyrA and Ser80Ile, Glu8Val mutations in ParC. These findings are consistent with reports that demonstrate that those SNPs are sufficient for high-level fluoroquinolone resistance and $a a c\left(6^{\prime}\right)-\mathrm{Ib}$-cr allele is insufficient to confer clinically significant ciprofloxacin resistance but augments resistance conferred by other mechanisms ${ }^{12,30}$. The presence of the plasmid in two different Escherichia strains from the same host strongly suggests in vivo transmission.

pMB2 does not have a carrying cost. We hypothesized that the large size of pMB2 would slow the growth of laboratory strain $\mathrm{DH} 5 \alpha$. In rebuttal of our hypothesis, $\mathrm{DH} 5 \alpha$ carrying $\mathrm{pMB} 2$ grew at rates that were comparable to or faster than the plasmid-free strain. This occurred in Luria broth (LB) (Fig. 3) as well as in nutrient broth, 


\begin{tabular}{|c|c|c|c|c|c|c|c|c|c|c|c|}
\hline & \multicolumn{8}{|c|}{ Zone diameters $(\mathrm{mm})$ and CLSI interpretations } & \multicolumn{3}{|c|}{$\begin{array}{l}\text { Minimum inhibitory } \\
\text { concentrations }(\mu \mathrm{g} / \mathrm{mL})\end{array}$} \\
\hline & C & S & NA & SUL & AMP & CIP & TE & $\mathbf{W}$ & NA & CIP & KM \\
\hline DH5 $\alpha$ E & $30 \mathrm{~S}$ & $23 \mathrm{~S}$ & $20 \mathrm{~S}$ & $50 \mathrm{~S}$ & $40 \mathrm{~S}$ & $42 \mathrm{~S}$ & $34 \mathrm{~S}$ & $22 \mathrm{~S}$ & 12 & 0.023 & $<7.5$ \\
\hline DH5 $\alpha$ E (pMB2) & $30 \mathrm{~S}$ & $22 \mathrm{~S}$ & $16 \mathrm{I}$ & $44 \mathrm{~S}$ & $6 \mathrm{R}$ & $34 \mathrm{~S}$ & 9R & $6 \mathrm{R}$ & 16 & 0.094 & $>30$ \\
\hline C600 & $24 \mathrm{~S}$ & $17 \mathrm{~S}$ & $6 \mathrm{R}$ & $36 \mathrm{~S}$ & $23 \mathrm{~S}$ & $26 \mathrm{~S}$ & $22 \mathrm{~S}$ & $30 \mathrm{~S}$ & $>256$ & 0.25 & $<7.5$ \\
\hline M63a & $21 \mathrm{~S}$ & $14 \mathrm{I}$ & $22 \mathrm{~S}$ & $6 \mathrm{R}$ & $6 \mathrm{R}$ & $39 \mathrm{~S}$ & $6 \mathrm{R}$ & $6 \mathrm{R}$ & 6 & 0.023 & $<7.5$ \\
\hline M63b & $22 \mathrm{~S}$ & $13 \mathrm{I}$ & $21 \mathrm{~S}$ & $6 \mathrm{R}$ & $6 \mathrm{R}$ & $42 \mathrm{~S}$ & 7R & $6 \mathrm{R}$ & 6 & 0.016 & $<7.5$ \\
\hline M63c & $21 \mathrm{~S}$ & $10 \mathrm{R}$ & $6 \mathrm{R}$ & $6 \mathrm{R}$ & $6 \mathrm{R}$ & $6 \mathrm{R}$ & $6 \mathrm{R}$ & $6 \mathrm{R}$ & $>256$ & $>32$ & $>30$ \\
\hline M63e & $21 \mathrm{~S}$ & $14 \mathrm{I}$ & $21 \mathrm{~S}$ & $6 \mathrm{R}$ & $6 \mathrm{R}$ & $31 \mathrm{~S}$ & $6 \mathrm{R}$ & $6 \mathrm{R}$ & 4 & 0.023 & $<7.5$ \\
\hline C63a & $21 \mathrm{~S}$ & $14 \mathrm{I}$ & $22 \mathrm{~S}$ & $24 \mathrm{~S}$ & $15 \mathrm{I}$ & $42 \mathrm{~S}$ & $17 \mathrm{I}$ & $24 \mathrm{~S}$ & 4 & 0.023 & $<7.5$ \\
\hline C63c & $22 \mathrm{~S}$ & $16 \mathrm{~S}$ & $25 \mathrm{~S}$ & $30 \mathrm{~S}$ & $19 \mathrm{I}$ & $38 \mathrm{~S}$ & $21 \mathrm{~S}$ & $25 \mathrm{~S}$ & 4 & 0.023 & $<7.5$ \\
\hline
\end{tabular}

Table 2. Antimicrobial susceptibility profiles of Escherichia isolates from the mother-infant pair from whom plasmid pMB2 were recovered and $\mathrm{DH} 5 \alpha$ with and without $\mathrm{pMB} 2$. Data are zone diameters in $\mathrm{mm}$ and CLSI interpretations $(\mathrm{R}=$ resistant, $\mathrm{I}=$ intermediate; $\mathrm{S}=$ sensitive $)$ and minimum inhibitory concentrations. A nalidixic acid-resistant derivative of E. coli C600 was used as a quinolone-resistant control. Key Chloramphenicol (C), Streptomycin (S), Nalidixic Acid (NA), Sulfonamide (S), Ampicillin (AMP), Ciprofloxacin (CIP), Tetracycline (TE), Trimethoprim (W); Resistant (R), Susceptible (S), Intermediate (I). Strains M63a-e are from a mother enrolled in the study of Odetoyin et al. ${ }^{17}$ and strains C63a and c are isolates from her child.

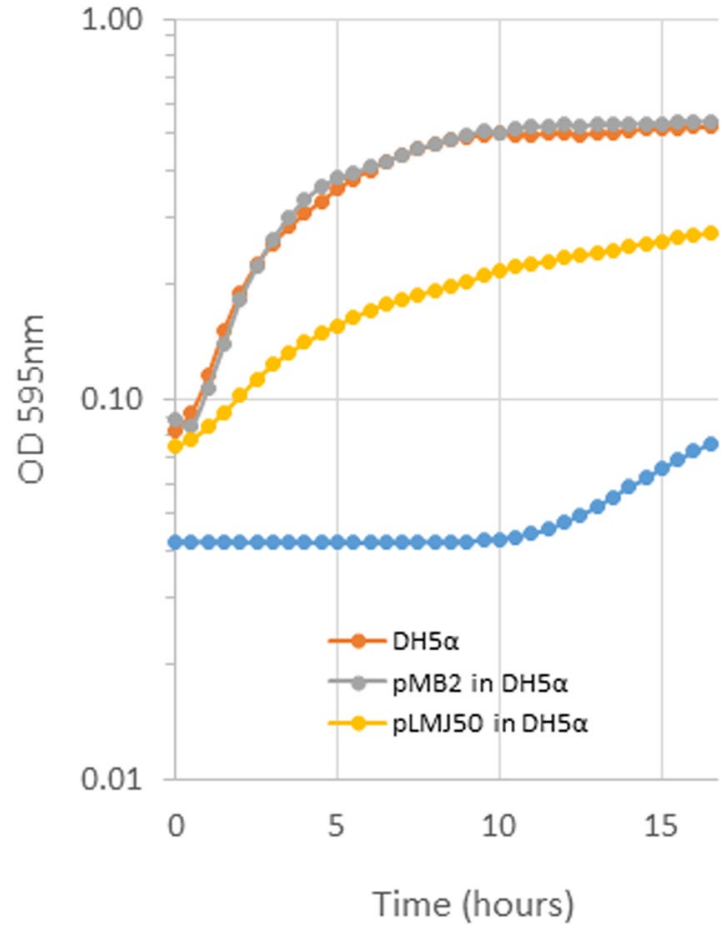

Figure 3. $18 \mathrm{~h}$ growth time-course of $\mathrm{DH} 5 \alpha$ (orange), $\mathrm{DH} 5 \alpha$ carrying $125 \mathrm{~Kb}$ plasmid pMB2 (grey) and $90 \mathrm{~Kb}$ plasmid pLMJ50 (yellow) in LB broth. The blue circles represent a no bacteria control.

terrific broth, Dubelcco's Modified Eagle Medium (DMEM, Invitrogen), Davis minimal medium and M9 minimal medium (data not shown). As a control, we used a $92 \mathrm{~kb}$ aggregative adherence impAB plasmid, pLMJ50 ${ }^{31}$, which did demonstrate a significant carrying cost in DH5 $\alpha$ (Fig. 3).

Characterization of pMB2. To determine whether nutrient acquisition conferred by the pMB2 region harboring transport systems operons pMB2_00012/hemR and sitABCD located at 7,247-8,038 bp and 19,195$22,644 \mathrm{bp}$ respectively on pMB2 offsets the carrying cost of pMB2, this segment of the plasmid was excised. A 32,331 bp segment that included these genes was deleted from the plasmid by excision with Not1 (NEB), which cuts pMB2 at 122,777 bp, and Xba1 (NEB), which cuts pMB2 at 29,449 bp. The restricted ends were filled in using E. coli DNA polymerase I (NEB) and then ligated on one other to generate a $93,450 \mathrm{bp}$ autonomously-replicating 


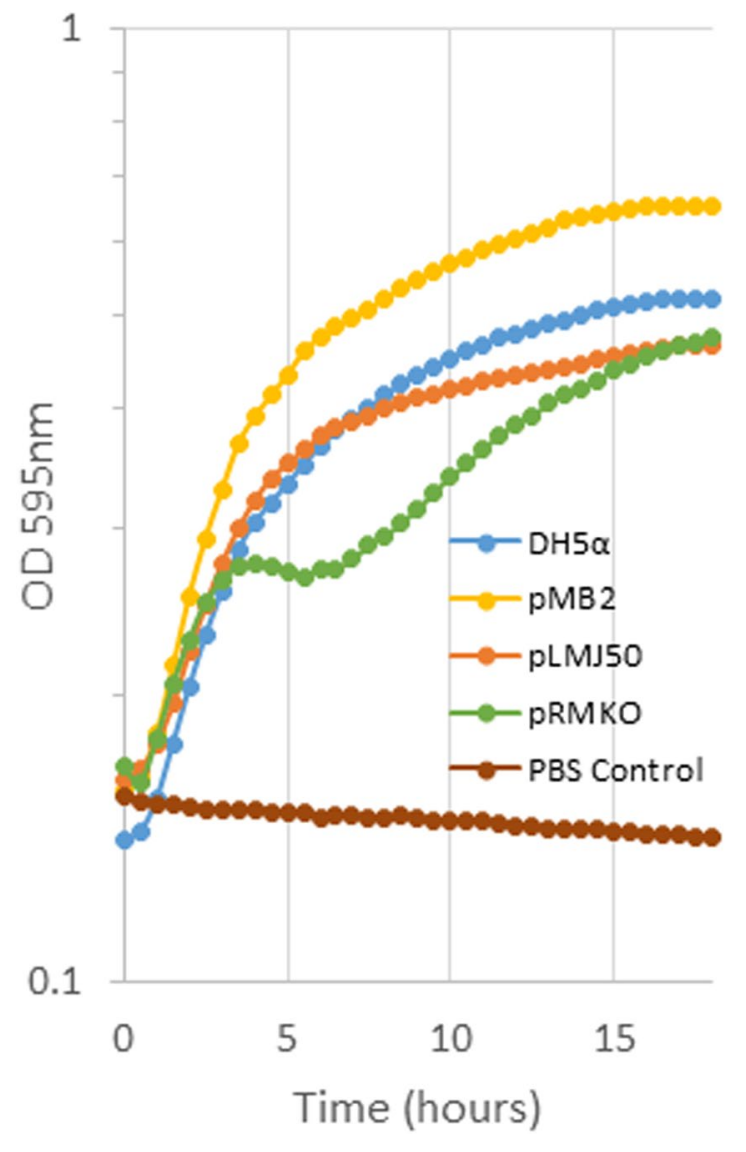

Figure 4. $18 \mathrm{~h}$ growth time-course of $\mathrm{DH} 5 \alpha$ carrying the pRMKO miniplasmid derived from pMB2 (green) compared to growth of DH5 $\alpha$ (blue), DH5 $\alpha$ carrying pMB2 (yellow) and $90 \mathrm{~Kb}$ control plasmid pLMJ50 (orange) in LB broth. Brown circles represent a no bacterial control.

mini-plasmid, pRMKO. The excised 32,331 bp fragment containing the transport system region was cloned into the XbaI and NotI sites of pBluescript II SK (Agilent) and named pRMC.

As seen in Fig. 4, the LB growth data, the equivalent or faster growth conferred by pMB2 was not seen with the mini-plasmid pRMKO, which grew at a rate that was slower than equivalent-sized plasmid pLMJ50. Intriguingly, $\mathrm{pRMC}$, the cloned deleted region also conferred slower growth than wildtype, although in this case the carrying cost may be attributed to the higher copy number of the clone. Attempts to move the large insert to a lower copy-number vector were not successful and therefore it was not possible to fully complement the mini-plasmid deletion in trans. We therefore elected to functionally characterize the sit $A B C D$ genes that are within the deleted sequence.

We amplified the sitABCD operon and its promoter from plasmid pSIT1 (which has an identical copy of the genes) received from Laura Runyen-Janecky ${ }^{26}$, using primers sitF and sitR and cloned them into pACYC177 to create pINK2301. In Davis minimal media iron-depleted by EDDA, DH5 $\alpha$ grows much slower than M63c, the E. coli strain from which $\mathrm{pMB} 2$ was isolated. Transformation of $\mathrm{DH} 5 \alpha$ with $\mathrm{pMB} 2$ produced a faster growth rate that was lower in DH5 $\alpha$ (pRMKO). As shown in Fig. 5, this growth defect could be complemented in trans with pINK2301.

To determine whether pMB2 enhanced bacterial fitness, we conducted competition experiments between strain M63c, the strain from which pMB2 was originally isolated, and commensal E. coli strain HS. We also competed DH5 $\alpha$ strains carrying pMB2 and pRMKO against one another. These experiments were performed in rich media (LB) as well as in DMEM in the absence of antibiotics, however antibiotics were used to select competitors on plates to perform counts. In both media, strains carrying pMB2 outcompeted commensal or laboratory strains. Conversely, DH5 $\alpha$ (pRMKO) suffered a competitive disadvantage against DH5 $\alpha$ (pMB2), as well as against plasmidless DH5 $\alpha$ (Fig. 6).

We sought to determine whether the plasmids were stably inherited and found that this was the case in source strain M63c over 200 generations. However, pMB2 and pRMKO were less stably inherited in a DH5 $\alpha$ background, with pRMKO proving to be less stably inherited than pMB2 in the medium term (Fig. 7).

\section{Discussion}

In this study, we identified and characterized pMB2 a multidrug resistance plasmid extracted from an Escherichia strain isolated in Nigeria. We were drawn to the plasmid by its $a a c\left(6^{\prime}\right)-I b$-cr gene but its resistance region also includes genes encoding resistance to seven other classes of antimicrobials, including the ESBL gene $b l a_{C T X-M-15}$. There have been several reports of co-occurrence of $b l a_{C T X-M-15}$ and $a a c\left(6^{\prime}\right)-I b$-cr across of the globe, including in 


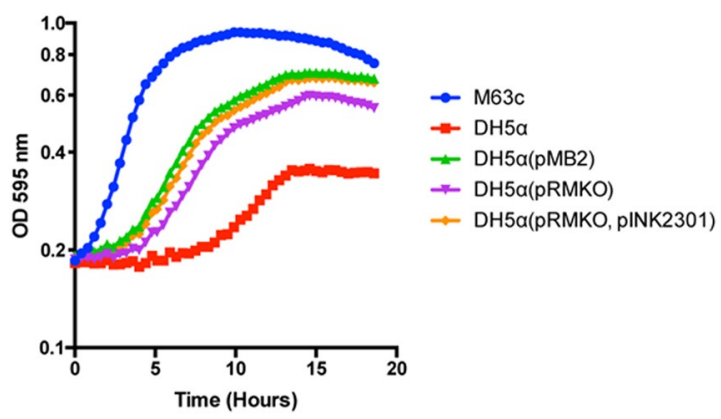

Figure 5. $18 \mathrm{~h}$ growth time-course in Davis minimal media pre-treated with deferrated EDDA to deplete iron. Wildtype M63c strain (grey) compared to DH5 $\alpha$ (orange), DH5 $\alpha$ carrying pMB2 (green), pRMKO miniplasmid (yellow), pRMKO miniplasmid plus the cloned sit genes in pINK2301 and $90 \mathrm{~Kb}$ control plasmid pLMJ50 (blue).

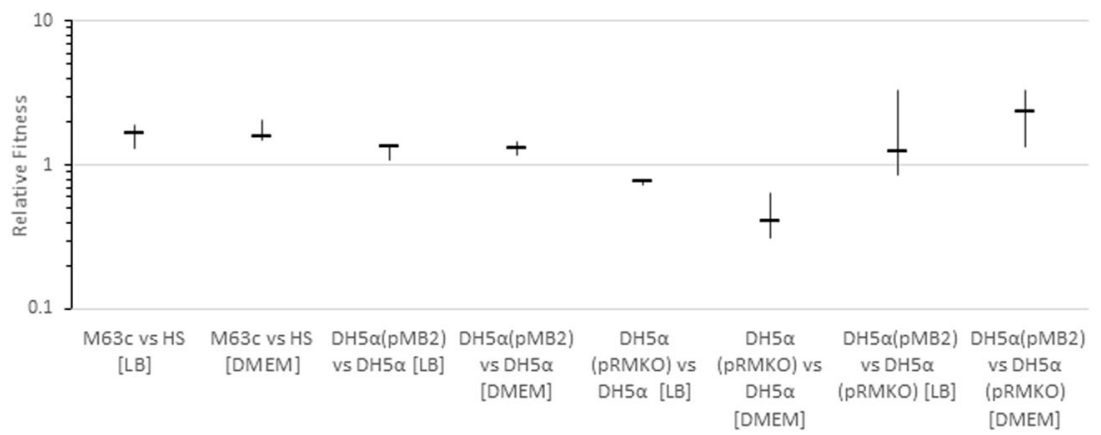

Figure 6. Relative fitness of the initially listed strain compared to the subsequently listed strain in rich media (LB) and minimal media (DMEM). Each data point is the mean of duplicate experiments and the error bars are the computed standard deviations.

Nigeria $^{32-35}$. This common co-resistance profile implies that ciprofloxacin use, which is growing ${ }^{1}$, also selects for the carriage of ESBL genes and vice versa explaining why IncFII plasmids carrying these genes have traditionally been associated with successful pandemic clones ${ }^{36,37}$. This report appears to be the first one directly confirming a genetic linkage of $b l a_{C T X-M-15}$ and $a a c\left(6^{\prime}\right)-I b-c r$ in Nigeria. However the structure of this plasmid in general and the resistance region in particular has been reported from round the world.

When resistance is conferred by a plasmid of considerable size, the associated metabolic burden on the organism due to the additional energy required in replication and gene expression typically exerts a carrying cost, at least theoretically ${ }^{38}$. In practice, this is not always true but the co-evolutionary routes to reduced cost are often unknown. Some research has suggested that this burden is reduced or eliminated through compensatory mutations or acquisitions ${ }^{14,39-43}$. Alternatively, or in addition, plasmid-encoded resistance genes themselves could confer a fitness advantage in the absence of antimicrobials ${ }^{14,41}$.

Antimicrobial use is the principal driving force behind the current epidemic of antimicrobial resistance. However, research has shown that, once evolved, multidrug resistance plasmids can be maintained in the absence of selection ${ }^{44}$. There is a dearth of fitness defects reported for resistance plasmids in the literature and the reasons why some of them are evolutionarily successful are not well understood ${ }^{41,45}$. This study demonstrates that the $a a c\left(6^{\prime}\right)-I b-c r$ gene of strain M63c is carried on a large multidrug resistance plasmid pMB2, which also bears a number of genetic loci that support its evolutionary success irrespective of antibiotic selection. The $125 \mathrm{~Kb}$ plasmid does not have a carrying cost in vitro and competition experiments verified that $32 \mathrm{~Kb}$ region of the plasmid accounts for selective success. Included in this evolutionarily significant $32 \mathrm{~Kb}$ region are the sit $A B C D$ genes, which promote growth under iron-limited conditions, along with as yet unidentified loci that promote growth in rich and minimal media. The sit $A B C D$ and adjacent genes studied in our research are highly conserved among most of them and therefore the fitness they confer is also likely to be common. Overall, these data suggest that fitness conferring mobile elements associated with resistance can co-evolve with host bacteria to compensate the costs of their carriage and propagate its transmission irrespective of antibiotic selection. While in vivo fitness is yet to be evaluated for these loci, and should be an area of future study, the in vitro advantages conferred were substantial. Without a carrying cost large multidrug resistance plasmids could persist in commensal E. coli even in the absence of antimicrobial pressure. Future work on resistance plasmids and elements should focus more intently on fitness genes in addition to those that encode drug resistance. 

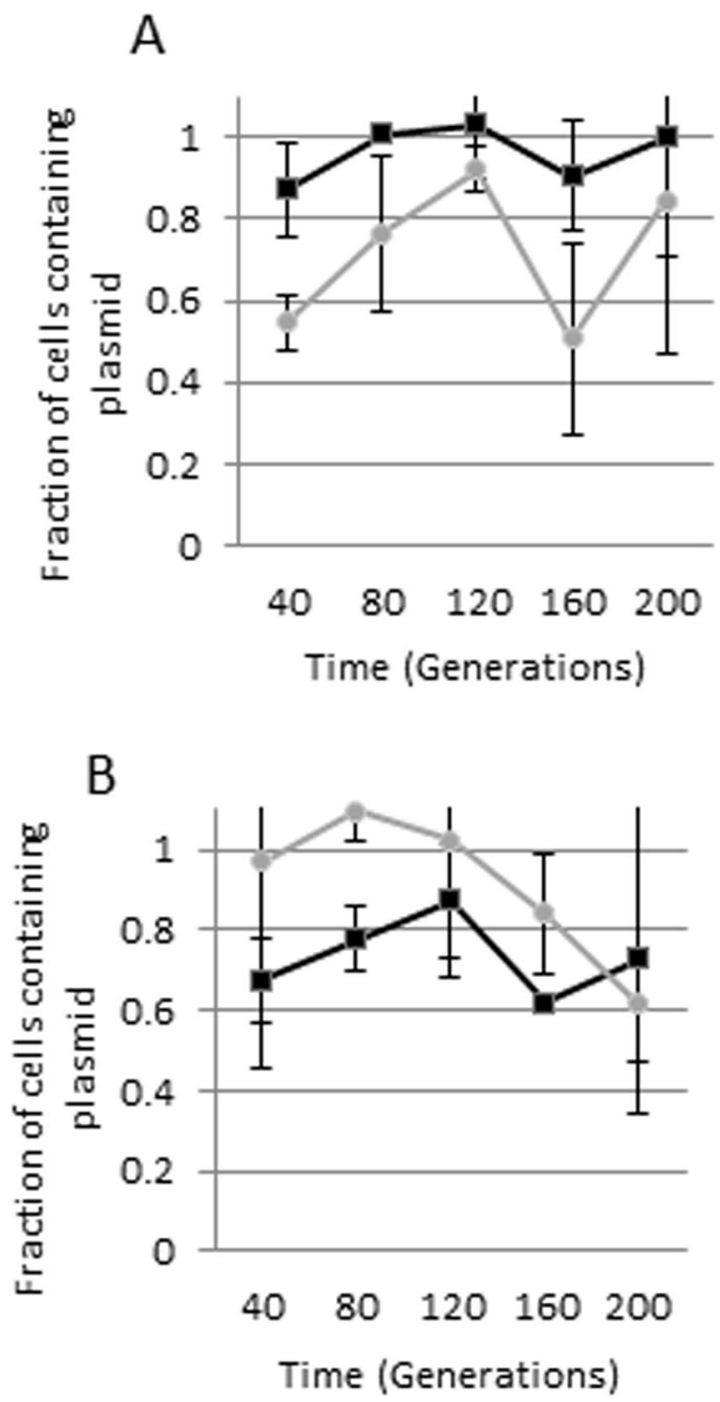

Figure 7. Plasmid stability in the absence of selection (A) stability of pMB2 in M63c, its natural host (dark line) and control plasmid pBR322 in DH5 $\alpha$ (grey line) (B) stability of pMB2 (grey line) and pRMKO (dark line) in DH5 $\alpha$.

\section{Methods}

Ethical considerations. Permission to conduct this study was granted by the Ethics and Research committee of Obafemi Awolowo University Teaching Hospitals Complex, Ile-Ife with approval number IEC No. 00005422. Patients or their parents and guardians from whom the strains were isolated gave informed consent to participate in the study and all procedures were performed in accordance with the ethics committee's guidelines and requirements.

Strains. Strains used in this study are listed in Table 3. Commensal E. coli were collected from Nigerian mother-infant pairs where the infant suffered from diarrhea as previously described ${ }^{17}$. Altogether stool samples from 134 mothers-infant pairs, yielded 1,098 E. coli isolates for evaluation. Routine culture of bacteria was performed aerobically at $37^{\circ} \mathrm{C}$ in Luria broth supplemented with chloramphenicol $(30 \mu \mathrm{g} / \mathrm{mL})$, ampicillin $(100 \mu \mathrm{g} / \mathrm{mL})$, tetracycline $(25 \mu \mathrm{g} / \mathrm{mL})$, or neomycin $(50 \mu \mathrm{g} / \mathrm{mL})$ where applicable. Strains were maintained at $-70^{\circ} \mathrm{C}$ in Luria broth:glycerol 1:1.

Antimicrobial susceptibility testing. Antimicrobial susceptibility testing was performed using the Clinical and Laboratory Standards Institute (CLSI) disc diffusion method and interpreting zone diameters in accordance with CLSI guidelines in WHONET software version $5.3^{46}$. Discs used contained ampicillin $(10 \mu \mathrm{g} / \mathrm{ml})$, streptomycin $(10 \mu \mathrm{g})$, trimethoprim $(5 \mu \mathrm{g})$, tetracycline $(30 \mu \mathrm{g})$, nalidixic acid $(30 \mu \mathrm{g})$, chloramphenicol $(300 \mu \mathrm{g})$, sulphonamide $(1000 \mu \mathrm{g})$ and ciprofloxacin $(5 \mu \mathrm{g})$ (Oxoid/Remel). E. coli ATCC 35218 and DH5 $\alpha$ E (Invitrogen) were used as control strains. Minimum inhibitory concentrations (MICs) for nalidixic acid and ciprofloxacin were determined using E-test (bioMérieux) on Mueller-Hinton (MH) agar. Kanamycin MICs were determined by agar dilution on Mueller-Hinton Agar. 


\begin{tabular}{|c|c|c|}
\hline & Genotype and description & Reference or Source \\
\hline M63c & E. coli wt, $\mathrm{S}^{\mathrm{R}}, \mathrm{Nal}^{\mathrm{R}}, \mathrm{Sul}^{\mathrm{R}}, \mathrm{Amp}^{\mathrm{R}}, \mathrm{Cip}^{\mathrm{R}}, \mathrm{Te}^{\mathrm{R}}, \mathrm{W}^{\mathrm{R}}, \mathrm{K}^{\mathrm{R}}$ & 17 \\
\hline M63a, M63b, M63d, M63d & E. coli isolates recovered from the same specimen as M63c & 17 \\
\hline $\mathrm{C} 63 \mathrm{a}, \mathrm{C} 63 \mathrm{c}$ & $\begin{array}{l}\text { E. coli isolate obtained from a specimen collected on the same day, from the infant of } \\
\text { research participant whose stool yielded M63c }\end{array}$ & 17 \\
\hline DH5 $\alpha$ & 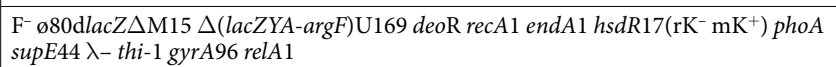 & Invitrogen \\
\hline $\mathrm{C} 600 \mathrm{Nal}^{\mathrm{R}}$ & Nalidixic acid-resistant derivative of $\mathrm{C} 600$. & 68 \\
\hline NCTC 10418 & Susceptibility testing control & \\
\hline ATCC 35218 & Susceptibility testing control & \\
\hline EC1502 & Rifampicin-resistant, plasmid free E. coli strain & University of Bradford \\
\hline HS & $\begin{array}{l}\text { Commensal E.coli strain that has been shown to colonize non-virulently in human } \\
\text { volunteer studies }\end{array}$ & 69 \\
\hline
\end{tabular}

Table 3. Strains used in this study.

General microbiology and molecular biology procedures. The Promega Wizard ${ }^{\circledR}$ kit was used for genomic DNA extractions and plasmids under $20 \mathrm{~Kb}$ were extracted using a Qiagen ${ }^{\circledR}$ MiniPrep Kit. Naturally-occurring low copy number larger plasmids were extracted, after growth of host bacterium in Terrific Broth and induction with chloramphenicol, by a modified boiling protocol for small scale preparations ${ }^{47,48}$ and using the Qiagen ${ }^{\circledR}$ Large Construct Kit for large-scale preparations. Table 4 lists the plasmids used in the study, their relevant properties, and their sizes. Plasmids were electroporated into E. coli host strains using a Bio-Rad micropulser according to manufacturer's instructions. Sequences of oligonucleotide primers used in the study are listed in Supplementary Table 1. Amplification cycles began with a two-minute hot start at $94^{\circ} \mathrm{C}$ followed by 30 cycles of denaturing at $94^{\circ} \mathrm{C}$ for $30 \mathrm{~s}$, annealing at $5^{\circ} \mathrm{C}$ below the melting temperature (unless otherwise specified) for $30 \mathrm{~s}$, and extending at $72^{\circ} \mathrm{C}$ for one minute per kilobase of DNA to be amplified. BstCI restriction analysis of $a a c\left(6^{\prime}\right)$-Ib PCR amplicons were used to determine whether they represented the ciprofloxacin resistance conferring $a a c\left(6^{\prime}\right)-I b$-cr allele as it only differes by two SNPs and is therefore indistinguishable by $\mathrm{PCR}^{49}$. Up to two amplicons from each unique profile were sequenced to confirm PCR-RFLP-based classification. Where necessary, PCR amplicons were TA-cloned into the pGEMT vector (Promega) according to manufacturer's directions and plasmids were transformed into chemically competent $E$. coli K-12 TOP10 cells for sequencing. Other molecular biology operations were performed using standard procedures ${ }^{50}$.

Bacterial identification. Bacteria were identified to the species level as described previously ${ }^{17}$ and further biotyped on the API20E system (bioMérieux). Genetic identification was performed by $16 \mathrm{~S}$ ribosomal subunit sequencing, amplifying the gene encoding M63c's $16 \mathrm{~S}$ rRNA with primers 10 and 1507R (Supplemental Table 1) in a thermocycler using the cycle at $94^{\circ} \mathrm{C}$ for $2 \mathrm{~m},\left[94^{\circ} \mathrm{C}\right.$ for $30 \mathrm{~s}, 59^{\circ} \mathrm{C}$ for $45 \mathrm{~s}, 72^{\circ} \mathrm{C}$ for $\left.90 \mathrm{~s}\right] \mathrm{x} 36$, and $72^{\circ} \mathrm{C}$ for $10 \mathrm{~m}^{51}$. Multilocus sequence typing (MLST) was performed by amplifying the adk, fumC, gyrB, icd, $m d h$, purA and $r e c A$ genes using the primers of Wirth $e t$ al. as previously described ${ }^{52,53}$. PCR amplicons for sequencing were size-verified by agarose electrophoresis, cloned into pGEMT, and electroporated into DH5 $\alpha \mathrm{E}$ (Thermo Scientific) using a Biorad Micropulser. Plasmids were extracted with a Qiagen Plasmid Mini Kit and Sanger sequenced from M13F and M13R priming sites.

Shot-gun sequencing and sequence analysis. Whole-replicon shotgun library preparation, Sanger sequencing and assembly of plasmid pMB2 was performed by SeqWright DNA Technology Services (Houston, TX). Preliminary sequence analyses and annotation was performed manually by four authors in $\mathrm{Artemis}^{54}$ with open reading frames initially predicted using Glimmer ${ }^{55-57}$ and basing gene annotations on $98 \%$ or greater identity at the nucleotide and amino acid levels if BLAST e-value was $0^{58}$. Plasmid MLST typing was performed in silico, using PlasmidFinder and pMLST versions $2.0^{59}$. Open Reading Frame (ORF) identity was determined using BLAST and Pfam ${ }^{56,57}$. Two automated annotations were performed using BASys ${ }^{55}$ and Prokka v 1.13.3 $3^{60}$. Five authors resolved annotation discrepancies among automated and manual annotations. Antimicrobial resistance genes and their genetic context were searched using Galileo AMR (https://galileoamr.arcbio.com/mara/) ${ }^{61}$ and ResFinder ${ }^{58}$. Direct and inverted repeats were identified by dot-plot analysis of pairwise FASTA alignments made using the BLAST suite. ORF and feature plots were prepared using BLAST ring image generator ${ }^{62}$.

In vitro conjugation. In vitro conjugation experiments were performed by solid-surface matings. Donors and recipients were cultured in LB with appropriate selective antimicrobials. $0.5 \mathrm{~mL}$ of donor and recipient culture, grown overnight with selection, was spun down at $5000 \mathrm{rpm}$ for 5 minutes in a fixed rotor microcentrifuge and resuspended in $20 \mu \mathrm{l}$ of LB without antibiotics. The suspension was spotted onto dried LB plates, allowed to dry at room temperature for 15 minutes and then incubated at $37^{\circ} \mathrm{C}$ for three hours. The mating reaction was resuspended in $1 \mathrm{ml}$ of LB with vortexing and placed on ice to terminate conjugation. After mating, serial ten-fold dilutions of each terminated reaction was made in cold phosphate buffered saline and plated onto plates containing tetracycline (or other appropriate antimicrobials for controls) - to select for the plasmid-and nalidixic acid-resistance to which is conferred chromosomally in the recipient. Transconjugant colonies were counted after overnight incubation at $37^{\circ} \mathrm{C}$ and up to 50 colonies were verified by plasmid profiling, phenotype on MacConkey and Eosin methylene blue agars, PCR-RFLP for the $f l i C$ allele ${ }^{63}$, and PCR for donor- and 


\begin{tabular}{|l|l|l|l|}
\hline Plasmid & Description & Size & $\begin{array}{l}\text { Reference } \\
\text { or source }\end{array}$ \\
\hline pMB2 & Naturally occurring $a a c\left(6^{\prime}\right)$-Ib-cr-bearing plasmid & $125 \mathrm{~Kb}$ & $\begin{array}{l}\text { This study } \\
\text { and }^{19}\end{array}$ \\
\hline pMB80-2 & $\begin{array}{l}\text { Naturally occurring conjugative plasmid from } \\
\text { enteropathogenic E. coli strain }\end{array}$ & $>100 \mathrm{~Kb}$ & 48 \\
\hline pRMKO & $\begin{array}{l}\text { Mini-plasmid constructed by deleting a 32,331 bp Not1 - Xbal } 1 \\
\text { fragment from pMB2 }\end{array}$ & $93 \mathrm{~Kb}$ & This study \\
\hline pRMC & $\begin{array}{l}\text { pBluescript II SK containing a 32,331 bp Not1 - Xbal fragment } \\
\text { from pMB2 cloned }\end{array}$ & $35 \mathrm{~Kb}$ & This study \\
\hline pBAD/Thio-TOPO & Arabinose inducible expression vector & $4,454 \mathrm{bp}$ & Invitrogen \\
\hline pBluescript II SK + & High copy number cloning vector & $2,961 \mathrm{bp}$ & Agilent \\
\hline pSIT1 & Clone of the Shigella sitABCD genes & & 70 \\
\hline pINK2301 & Shigella sitABCD genes subcloned from pSIT1 into pACYC177 & $7.1 \mathrm{~Kb}$ & This study ${ }^{19}$ \\
\hline pLMJ50 & $\begin{array}{l}\mathrm{Cm}^{\mathrm{R}} ; \text {;arge aggregative adherence plasmid from EAEC strain } \\
60 \mathrm{~A} \text { in which the imp } B \text { gene is replaced with a cat cassette }\end{array}$ & $90 \mathrm{~Kb}$ & 31 \\
\hline pGEM-T & $\mathrm{Amp}^{\mathrm{R}} ; \mathrm{TA}^{-c l o n i n g}$ vector & $3,000 \mathrm{bp}$ & Promega \\
\hline pBR322 & $\mathrm{Amp}^{\mathrm{R}}, \mathrm{Tc}^{\mathrm{R}}$ cloning vector & $4,363 \mathrm{bp}$ & $\mathrm{NEB}$ \\
\hline pACYC177 & $\mathrm{Amp}^{\mathrm{R}}, \mathrm{Km}^{\mathrm{R}}$ cloning vector & $3,941 \mathrm{bp}$ & NEB \\
\hline
\end{tabular}

Table 4. Plasmids used in this study.

recipient-specific markers. Viable counts of donors and recipient were also performed. The number of transconjugant colonies per donor colony-forming units was computed as the plasmid transfer efficiency ${ }^{64}$

Growth curves. Growth curves were plotted following growth of each strain in microtiter wells containing $160 \mu \mathrm{l}$ of media in an Infinite ${ }^{\circledR} 2000$ Pro Series microplate reader preset at $37^{\circ} \mathrm{C}$ (Tecan). Commercially available medias were prepared as recommended by the manufacturers. Iron-depleted media was prepared by adding deferrated ethylene diamino-o-dihydroxyphenyl acetic acid (EDDA) as described previously ${ }^{65}$. Test strains were first cultured overnight in $5 \mathrm{~mL}$ of LB media containing appropriate antibiotics where required. Overnight cultures were spun down, resuspended in $5 \mathrm{~mL}$ of $1 \mathrm{X}$ Phosphate Buffered Saline (PBS), and diluted to an optical density of 0.70 at $595 \mathrm{~nm} .10 \mu \mathrm{l}$ of the diluted cultures were then loaded into assigned wells in the microtiter reader. Absorbance was measured at $595 \mathrm{~nm}$ every $30 \mathrm{~min}$ preceded by $30 \mathrm{sec}$ of orbital shaking for 24 hours. The average optical density of 25 reads per well at each time point was used in the analysis and up to six wells were tested per strain. Each specific strain and conditions was tested on a minimum of three occasions.

Plasmid stability. Plasmid stability was assessed by serially passaging E. coli strains carrying pMB2 and its derivatives as described by Sandegren et al. ${ }^{66}$. Triplicate starting cultures were grown overnight at $37^{\circ} \mathrm{C}$ in $1 \mathrm{~mL}$ of LB supplemented with ampicillin or tetracycline. Bacterial cells were washed, resuspended in LB without antibiotics and an aliquot of $100 \mu \mathrm{L}$ of washed cells was inoculated into $10 \mathrm{~mL}$ of $\mathrm{LB}$ in a $50 \mathrm{~mL}$ conical tube and incubated overnight at $37^{\circ} \mathrm{C} .100 \mu \mathrm{L}$ of this overnight culture was serial passaged to $1 \mathrm{~mL}$ of LB daily, approximating 10 generations of growth per passage. At select time points, samples were diluted and plated onto plain MacConkey plates and MacConkey plates containing tetracycline.

In vitro competition experiments. We measured relative fitness in traditional competition assays as outlined by Wiser and Lenski ${ }^{67}$. Fitness was computed independently in LB broth and DMEM and E. coli strains carrying pMB2 and its derivative plasmids were selected using antibiotic markers present on those plasmids. Briefly, separate cultures of the competing strains were grown overnight in the test medium containing ampicillin at $37^{\circ} \mathrm{C}$ before volumes equivalent to equal optical densities were added to a $50 \mathrm{~mL}$ conical tube to a final volume of $\approx 0.1 \mathrm{ml}$, which was immediately made up to $10 \mathrm{~mL}$ with test medium. The culture was mixed, $100 \mu \mathrm{L}$ was withdrawn for viable counting (diluting with normal saline) and the culture was then incubated at $37^{\circ} \mathrm{C}$ with shaking. At $24 \mathrm{~h}, 100 \mu \mathrm{L}$ was withdrawn, diluted with normal saline, and plated out for counting. For wildtype strains, counting was performed on MacConkey agar plates containing ampicillin, tetracycline and no antibiotics. For strains carrying pMB2 or its mini-plasmid deletion construct, pRMKO, counting was performed on MacConkey agar plates containing ampicillin, Mueller Hinton tetracycline plates and Mueller Hinton trimethoprim plates. Differential computation of strains carrying pMB2 or pRMKO were made possible by the fact that pMB2's $d f r A 17$ gene, conferring trimethoprim resistance, is deleted from pRMKO. Fitness $(w)$ was calculated by comparing the ratio of competed bacterial strains obtained at $24 \mathrm{~h}, \mathrm{~A}_{\mathrm{f}}$ and $\mathrm{B}_{\mathrm{f}}$ hours respectively, with those computed from the sample drawn at $\mathrm{h}\left(\mathrm{A}_{\mathrm{i}}\right.$ and $\mathrm{B}_{\mathrm{i}}$, respective), that is, using the formula specified by Wiser and Lenski ${ }^{67}$

$$
w=\frac{\operatorname{In}\left(\mathrm{A}_{\mathrm{i}} / \mathrm{A}_{\mathrm{f}}\right)}{\operatorname{In}\left(\mathrm{B}_{\mathrm{i}} / \mathrm{B}_{\mathrm{f}}\right)}
$$

Received: 26 July 2019; Accepted: 2 December 2019;

Published online: 23 December 2019 


\section{References}

1. Lamikanra, A. et al. Rapid evolution of fluoroquinolone-resistant Escherichia coli in Nigeria is temporally associated with fluoroquinolone use. BMC Infect Dis. 11, 312, doi:1471-2334-11-312 (2011).

2. Strahilevitz, J., Jacoby, G. A., Hooper, D. C. \& Robicsek, A. Plasmid-mediated quinolone resistance: a multifaceted threat. Clin. Microbiol. Rev. 22, 664-689, https://doi.org/10.1128/cmr.00016-09 (2009).

3. Tran, J. H. \& Jacoby, G. A. Mechanism of plasmid-mediated quinolone resistance. Proc Natl Acad Sci USA 99, 5638-5642 (2002).

4. Robicsek, A., Jacoby, G. A. \& Hooper, D. C. The worldwide emergence of plasmid-mediated quinolone resistance. Lancet Infect Dis 6, 629-640 (2006).

5. Hansen, L. H., Johannesen, E., Burmølle, M., Sørensen, A. H. \& Sørensen, S. J. Plasmid-encoded multidrug efflux pump conferring resistance to olaquindox in Escherichia coli. Antimicrob Agents Chemother 48, 3332-3337 (2004).

6. Hansen, L. H., Jensen, L. B., Sørensen, H. I. \& Sørensen, S. J. Substrate specificity of the OqxAB multidrug resistance pump in Escherichia coli and selected enteric bacteria. J Antimicrob Chemother 60, 145-147, https://doi.org/10.1093/jac/dkm167 (2007).

7. Janatova, M. et al. Antimicrobial-resistant Enterobacteriaceae from humans and wildlife in Dzanga-Sangha Protected Area, Central African Republic. Vet Microbiol 171, 422-431, S0378-1135(14)00091-1 (2014).

8. Founou, L. L. et al. Genome Sequencing of Extended-Spectrum $\beta$-Lactamase (ESBL)-Producing Klebsiella pneumoniae Isolated from Pigs and Abattoir Workers in Cameroon. Frontiers in Microbiology 9, https://doi.org/10.3389/fmicb.2018.00188 (2018).

9. Kim, H. B. et al. oqxAB encoding a multidrug efflux pump in human clinical isolates of Enterobacteriaceae. Antimicrobial agents and chemotherapy 53, 3582-3584 (2009).

10. Osei Sekyere, J. Genomic insights into nitrofurantoin resistance mechanisms and epidemiology in clinical Enterobacteriaceae. Future Science OA 4, FSO293, https://doi.org/10.4155/fsoa-2017-0156 (2018).

11. Osei Sekyere, J. \& Amoako, D. G. Genomic and phenotypic characterisation of fluoroquinolone resistance mechanisms in Enterobacteriaceae in Durban, South Africa. PLOS ONE 12, e0178888, https://doi.org/10.1371/journal.pone.0178888 (2017).

12. Robicsek, A. et al. Fluoroquinolone-modifying enzyme: a new adaptation of a common aminoglycoside acetyltransferase. Nat Med 12, 83-88, https://doi.org/10.1038/nm1347 (2006).

13. Namboodiri, S. S., Opintan, J. A., Lijek, R. S., Newman, M. J. \& Okeke, I. N. Quinolone resistance in Escherichia coli from Accra, Ghana. BMC Microbiol 11, 44, doi:1471-2180-11-44 (2011).

14. Schaufler, K. et al. Carriage of Extended-Spectrum Beta-Lactamase-Plasmids Does Not Reduce Fitness but Enhances Virulence in Some Strains of Pandemic E. coli Lineages. Front. Microbiol 7, https://doi.org/10.3389/fmicb.2016.00336 (2016).

15. Ranjan, A. et al. ESBL-plasmid carriage in E. coli enhances in vitro bacterial competition fitness and serum resistance in some strains of pandemic sequence types without overall fitness cost. Gut Pathogens 10, 24, https://doi.org/10.1186/s13099-018-0243-z (2018).

16. Johnson, T. J. et al. Separate F-type plasmids have shaped the evolution of the H30 subclone of Escherichia coli sequence type 131. mSphere 1, e00121-00116, https://doi.org/10.1128/mSphere.00121-16 (2016).

17. Odetoyin, B. W., Hofmann, J., Aboderin, A. O. \& Okeke, I. N. Diarrhoeagenic Escherichia coli in mother-child Pairs in Ile-Ife, South Western Nigeria. BMC Infect Dis 16, 1 (2016).

18. Odetoyin, B. W., Labar, A. S., Lamikanra, A., Aboderin, A. O. \& Okeke, I. N. Classes 1 and 2 integrons in faecal Escherichia coli strains isolated from mother-child pairs in Nigeria. PLoS One 12, e0183383, https://doi.org/10.1371/journal.pone.0183383 (2017).

19. Sumrall, E. T., Gallo, E. B., Aboderin, A. O., Lamikanra, A. \& Okeke, I. N. Dissemination of the transmissible quinolone-resistance gene qnrS1 by IncX plasmids in Nigeria. PLoS ONE 9, e110279, https://doi.org/10.1371/journal.pone.0110279 (2014).

20. Maheux, A. F., Boudreau, D. K., Bergeron, M. G. \& Rodriguez, M. J. Characterization of Escherichia fergusonii and Escherichia albertii isolated from water. J Appl Microbiol 117, 597-609, https://doi.org/10.1111/jam.12551 (2014).

21. Helldal, L., Karami, N., Welinder-Olsson, C., Moore, E. R. \& Ahren, C. Evaluation of MLVA for epidemiological typing and outbreak detection of ESBL-producing Escherichia coli in Sweden. BMC Microbiol 17, 8, https://doi.org/10.1186/s12866-016-0922-1 (2017).

22. Blattner, F. R. et al. The complete genome sequence of Escherichia coli K-12. Science 277, 1453-1474 (1997).

23. Firth, N., Ippen-Ihler, K. \& Skurray, R. A. Structure and function of the F factor and mechanism of conjugation. Escherichia coli and Salmonella: cellular and molecular biology, 2nd ed. ASM Press, Washington, DC, 2377-2401 (1996).

24. Rodionov, D. A., Hebbeln, P., Gelfand, M. S. \& Eitinger, T. Comparative and functional genomic analysis of prokaryotic nickel and cobalt uptake transporters: evidence for a novel group of ATP-binding cassette transporters. J Bacteriol 188, 317-327 (2006).

25. Simpson, W., Olczak, T. \& Genco, C. A. Characterization and expression of HmuR, a TonB-dependent hemoglobin receptor of Porphyromonas gingivalis. Journal of bacteriology 182, 5737-5748 (2000).

26. Runyen-Janecky, L. J., Reeves, S. A., Gonzales, E. G. \& Payne, S. M. Contribution of the Shigella flexneri Sit, Iuc, and Feo iron acquisition systems to iron acquisition in vitro and in cultured cells. Infect Immun 71, 1919-1928 (2003).

27. Fisher, C. R. et al. Genetics and virulence association of the Shigella flexneri sit iron transport system. Infect Immun 77, 1992-1999 (2009).

28. Shaw, W. V. Chloramphenicol acetyltransferase: enzymology and molecular biology. CRC Crit Rev Biochem 14, 1-46, https://doi. org/10.3109/10409238309102789 (1983).

29. Lawley, T. D., Klimke, W. A., Gubbins, M. J. \& Frost, L. S. F factor conjugation is a true type IV secretion system. FEMS Microbiol Lett 224, 1-15, https://doi.org/10.1016/S0378-1097(03)00430-0 (2003).

30. Hopkins, K. L., Davies, R. H. \& Threlfall, E. J. Mechanisms of quinolone resistance in Escherichia coli and Salmonella: recent developments. Int J Antimicrob Agents 25, 358-373 (2005).

31. Joo, L. M., Macfarlane-Smith, L. R. \& Okeke, I. N. Error-prone DNA repair system in enteroaggregative Escherichia coli identified by subtractive hybridization. J Bacteriol 189, 3793-3803 (2007).

32. Aibinu, I., Odugbemi, T., Koenig, W. \& Ghebremedhin, B. Sequence type ST131 and ST10 complex (ST617) predominant among CTX-M-15-producing Escherichia coli isolates from Nigeria. Clin Microbiol Infect 18, E49-51, https://doi.org/10.1111/j.14690691.2011.03730.x (2012).

33. Aibinu, I. et al. Emergence of bla(CTX-M-15), qnrB1 and aac(6')-Ib-cr resistance genes in Pantoea agglomerans and Enterobacter cloacae from Nigeria (sub-Saharan Africa). J Med Microbiol 61, 165-167, doi:jmm.0.035238-0 (2012).

34. Iroha, I. R. et al. First description of Escherichia coli producing CTX-M-15- extended spectrum beta lactamase (ESBL) in outpatients from south eastern Nigeria. Ann Clin Microbiol Antimicrob 11, 19, doi:1476-0711-11-19 (2012).

35. Schaufler, K. et al. Genomic and Functional Analysis of Emerging Virulent and Multidrug-Resistant Escherichia coli Lineage Sequence Type 648. Antimicrob Agents Chemother 63, e00243-00219, https://doi.org/10.1128/aac.00243-19 (2019).

36. Coque, T. M. et al. Dissemination of clonally related Escherichia coli strains expressing extended-spectrum beta-lactamase CTX-M-15. Emerg Infect Dis 14, 195-200, https://doi.org/10.3201/eid1402.070350 (2008).

37. Lavollay, M. et al. Clonal dissemination of a CTX-M-15 beta-lactamase-producing Escherichia coli strain in the Paris area, Tunis, and Bangui. Antimicrob Agents Chemother 50, 2433-2438, doi:50/7/2433 (2006).

38. Morton, E. R., Merritt, P. M., Bever, J. D. \& Fuqua, C. Large deletions in the pAtC58 megaplasmid of Agrobacterium tumefaciens can confer reduced carriage cost and increased expression of virulence genes. Genome Biol Evol 5, 1353-1364 (2013).

39. Enne, V. et al. Assessment of the fitness impacts on Escherichia coli of acquisition of antibiotic resistance genes encoded by different types of genetic element. J Antimicrob Chemother 56, 544-551 (2005).

40. Loftie-Eaton, W. et al. Compensatory mutations improve general permissiveness to antibiotic resistance plasmids. Nature Ecology \& Evolution 1, 1354-1363, https://doi.org/10.1038/s41559-017-0243-2 (2017). 
41. San Millan, A. et al. Integrative analysis of fitness and metabolic effects of plasmids in Pseudomonas aeruginosa PAO1. The ISME Journal 12, 3014-3024, https://doi.org/10.1038/s41396-018-0224-8 (2018).

42. Harrison, E. et al. Rapid compensatory evolution promotes the survival of conjugative plasmids. Mobile Genetic Elements 6 , e1179074, https://doi.org/10.1080/2159256X.2016.1179074 (2016).

43. Mahérault, A.-C. et al. Advantage of the F2:A1:B- IncF Pandemic Plasmid over IncC Plasmids in In Vitro Acquisition and Evolution of CTX-M Gene-Bearing Plasmids in Escherichia coli. Antimicrobial Agents Chemother 63, e01130-01119, https://doi.org/10.1128/ aac.01130-19 (2019).

44. Mourand, G. et al. Rare Spontaneous Loss of Multiresistance Gene Carrying IncI/ST12 Plasmid in Escherichia coli in Pig Microbiota. Antimicrob Agents Chemother 60, 6046-6049, https://doi.org/10.1128/AAC.00864-16 (2016).

45. Carroll, A. C. \& Wong, A. Plasmid persistence: costs, benefits, and the plasmid paradox. Can J Microbiol 64, 293-304, https://doi. org/10.1139/cjm-2017-0609 (2018).

46. O’Brien, T. F. \& Stelling, J. M. WHONET: an information system for monitoring antimicrobial resistance. Emerg Infect Dis 1, 66 (1995).

47. Kado, C. I. \& Liu, S. T. Rapid procedure for detection and isolation of large and small plasmids. J Bacteriol 145, 1365-1373 (1981).

48. Nwaneshiudu, A. I., Mucci, T., Pickard, D. J. \& Okeke, I. N. A second large plasmid encodes conjugative transfer and antimicrobial resistance in O119:H2 and some typical O111 enteropathogenic Escherichia coli strains. J Bacteriol 189, 6074-6079 (2007).

49. Park, C. H., Robicsek, A., Jacoby, G. A., Sahm, D. \& Hooper, D. C. Prevalence in the United States of aac(6')-Ib-cr encoding a ciprofloxacin-modifying enzyme. Antimicrob Agents Chemother 50, 3953-3955 (2006). doi:AAC.00915-06.

50. Sambrook, J. \& Russell, D. W. Molecular cloning: a laboratory manual. 3rd edn, (Cold Spring Harbor Laboratory Press, 2001).

51. Mateos, M. et al. Heritable endosymbionts of Drosophila. Genetics 174, 363-376 (2006).

52. Wirth, T. et al. Sex and virulence in Escherichia coli: an evolutionary perspective. Mol Microbiol 60, 1136-1151 (2006).

53. Okeke, I. N. et al. Multi-locus sequence typing of enteroaggregative Escherichia coli isolates from Nigerian children uncovers multiple lineages. PLoS ONE 5, e14093 (2010).

54. Rutherford, K. et al. Artemis: sequence visualization and annotation. Bioinformatics 16, 944-945 (2000).

55. Van Domselaar, G. H. et al. BASys: a web server for automated bacterial genome annotation. Nucleic Acids Res 33, W455-W459 (2005).

56. Altschul, S. F., Gish, W., Miller, W., Myers, E. W. \& Lipman, D. J. Basic local alignment search tool. J Mol Biol 215, 403-410 (1990).

57. Finn, R. D. et al. The Pfam protein families database. Nucleic Acids Res 38, D211-D222, https://doi.org/10.1093/nar/gkp985 (2010).

58. Zankari, E. et al. Identification of acquired antimicrobial resistance genes. J. Antimicrob. Chemother. 67, 2640-2644, https://doi. org/10.1093/jac/dks261 (2012).

59. Carattoli, A. et al. In silico detection and typing of plasmids using PlasmidFinder and plasmid multilocus sequence typing. Antimicrob Agents Chemother 58, 3895-3903, https://doi.org/10.1128/AAC.02412-14 (2014).

60. Seemann, T. Prokka: rapid prokaryotic genome annotation. Bioinformatics 30, 2068-2069, https://doi.org/10.1093/bioinformatics/ btu153 (2014).

61. Partridge, S. R. \& Tsafnat, G. Automated annotation of mobile antibiotic resistance in Gram-negative bacteria: the Multiple Antibiotic Resistance Annotator (MARA) and database. J Antimicrob Chemother 73, 883-890, https://doi.org/10.1093/jac/dkx513 (2018).

62. Alikhan, N.-F., Petty, N. K., Ben Zakour, N. L. \& Beatson, S. A. BLAST Ring Image Generator (BRIG): simple prokaryote genome comparisons. BMC Genomics 12, 402, https://doi.org/10.1186/1471-2164-12-402 (2011)

63. Fields, P. et al. Molecular characterization of the gene encoding H antigen in Escherichia coli and development of a PCR-restriction fragment length polymorphism test for identification of E. coli O157:H7 and O157:NM. J. Clin. Microbiol. 35, 1066-1070 (1997).

64. Lu, J. et al. Analysis and characterization of the IncFV plasmid pED208 transfer region. Plasmid 48, 24-37 (2002).

65. Okeke, I. N., Scaletsky, I. C., Soars, E. H., Macfarlane, L. R. \& Torres, A. G. Molecular epidemiology of the iron utilization genes of enteroaggregative Escherichia coli. J Clin Microbiol 42, 36-44 (2004).

66. Sandegren, L., Linkevicius, M., Lytsy, B., Melhus, A. \& Andersson, D. I. Transfer of an Escherichia coli ST131 multiresistance cassette has created a Klebsiella pneumoniae-specific plasmid associated with a major nosocomial outbreak. J Antimicrob Chemother 67, 74-83, https://doi.org/10.1093/jac/dkr405 (2012).

67. Wiser, M. J. \& Lenski, R. E. A comparison of methods to measure fitness in Escherichia coli. PloS one 10, e0126210 (2015).

68. Appleyard, R. K. Segregation of New Lysogenic Types during Growth of a Doubly Lysogenic Strain Derived from Escherichia Coli K12. Genetics 39, 440-452 (1954).

69. Levine, M. M. et al. Escherichia coli strains that cause diarrhoea but do not produce heat- labile or heat-stable enterotoxins and are non-invasive. Lancet 1, 1119-1122 (1978).

70. Runyen-Janecky, L. J. \& Payne, S. M. Identification of chromosomal Shigella flexneri genes induced by the eukaryotic intracellular environment. Infect Immun 70, 4379-4388 (2002).

\section{Acknowledgements}

I.N.O. is an African Research Leader award supported by the UK Medical Research Council (MRC) and the UK Department for International Development (DFID) under the MRC/DFID Concordat agreement that is also part of the EDCTP2 program supported by the European Union. This work was also supported by a Branco Weiss Fellowship from the Society in Science, Zürich, Switzerland and by US National Science Foundation 'Research at Undergraduate Institutions' award MCB 0948460, both which were awarded to INO, and by undergraduate research studentships from Haverford College, PA, USA. BWO was the recipient of an International fellowship for Africa from American Society for Microbiology. We thank Drs David C Hooper, Alfredo G Torres and Laura Runyen-Janecky for strains. We are grateful to Erin Remaly, Rotimi Dada and Jennifer Hofmann for technical assistance and to Lawrence Wang for helpful comments.

\section{Author contributions}

I.N.O. conceived the study, which was designed by A.O.A. and I.N.O. R.M., M.B., O.C.-F., B.W.O., J.I.O.-V., N.K.Q. and I.N.O. performed experiments acquired the experimental data. R.M., M.B., O.C.-F., J.B., J.I.O.-V., L.P. and I.N.O. analyzed and interpreted the data. The initial draft was prepared by R.M., O.C.-F., A.O.A. and I.N.O. R.M., J.B., L.P., M.B. and I.N.O. prepared the figures. All the authors performed substantial revisions and approved the final version.

\section{Competing interests}

The authors declare no competing interests. 


\section{Additional information}

Supplementary information is available for this paper at https://doi.org/10.1038/s41598-019-56064-z.

Correspondence and requests for materials should be addressed to I.N.O.

Reprints and permissions information is available at www.nature.com/reprints.

Publisher's note Springer Nature remains neutral with regard to jurisdictional claims in published maps and institutional affiliations.

(c) (i) Open Access This article is licensed under a Creative Commons Attribution 4.0 International License, which permits use, sharing, adaptation, distribution and reproduction in any medium or format, as long as you give appropriate credit to the original author(s) and the source, provide a link to the Creative Commons license, and indicate if changes were made. The images or other third party material in this article are included in the article's Creative Commons license, unless indicated otherwise in a credit line to the material. If material is not included in the article's Creative Commons license and your intended use is not permitted by statutory regulation or exceeds the permitted use, you will need to obtain permission directly from the copyright holder. To view a copy of this license, visit http://creativecommons.org/licenses/by/4.0/.

(c) The Author(s) 2019 